\title{
A Rare Case of Human Papillomavirus- associated High-grade Neuroendocrine Carcinoma of the Hypopharynx
}

\author{
Chandra Sanwal $^{1}$, Gerard Voorhees ${ }^{2}$, Aaron Moon ${ }^{3}$, Thomas Turner ${ }^{4}$, Steven L. Gates ${ }^{5}$ \\ 1. Internal Medicine, Corpus Christi Medical Center, Corpus Christi, USA 2. Radiation Oncology, Corpus \\ Christi Cancer Center, Corpus Christi, USA 3. Radiology, Radiology Associates, Corpus Christi, USA 4. \\ Pathology, Corpus Christi Medical Center, Corpus Christi, USA 5. Geriatrics, Corpus Christi Medical \\ Center, Corpus Christi, USA
}

$\square$ Corresponding author: Chandra Sanwal, chandra_prakash@hotmail.com Disclosures can be found in Additional Information at the end of the article

\section{Abstract}

We present a case of primary small cell carcinoma of the hypopharynx (SCCH), with a rare association with human papillomavirus (HPV). A comparison is made to 11 previously known, well-documented cases of SCCH with a review of the literature concerning SCCH. Our patient's age of 23 years is the lowest among all previously reported cases, with an age range of 35-75. HPV association with SCCH is a rare new entity and eight HPV subtypes were identified in our case by ribonucleic acid (RNA) in-situ hybridization. The important common features among the previously reported 11 cases and our case include: (a) piriform sinus of the hypopharynx as the primary site in all cases, (b) a majority of patients presented with dysphagia and a neck mass, and (c) most patients had locoregional involvement at the time of presentation as opposed to distant metastasis. HPV-associated SCCH is extremely rare, with potentially aggressive clinical behavior, and needs much more research to further elucidate both the diagnostic and therapeutic approaches.

Received 02/14/2019

Review began 02/19/2019

Review ended 02/22/2019

Published 02/26/2019

\section{(C) Copyright 2019}

Sanwal et al. This is an open access article distributed under the terms of the Creative Commons Attribution License CC-BY 3.0., which permits unrestricted use, distribution, and reproduction in any medium, provided the original author and source are credited.
Categories: Oncology

Keywords: small cell carcinoma, human papilloma virus, neuroendocrine carcinoma, hypopharynx, piriform sinus, human papillomavirus

\section{Introduction}

Small cell lung (SCC) neuroendocrine carcinomas (NECCs) are aggressive, with poor prognosis, and a mean survival of two to four months without treatment [1]. SCC in extrapulmonary sites (EPS) accounts for $<2.5 \%-5 \%$ of all cases of SCC [1]. EPS are the esophagus, larynx, and bladder. The larynx is the most common site in the head and neck and SCC of the larynx accounts for $<0.5 \%$ of all laryngeal carcinomas [1]. SCC of the hypopharynx (SCCH) is extremely rare. There are only 11 reported cases of SCCH to date [2]. The first case was reported in 1980 [2]. This case report presents the twelfth case of SCCH. We compare the characteristics of our case with the previously known 11 cases of SCCH with respect to rare new features and common characteristics reported in the previous cases. Our case is confirmed to be associated with eight different human papillomavirus (HPV) subtypes, which is a rare new entity. Among all the 12 reported cases of SCCH, we compare the age of diagnosis, anatomic location of the primary tumor, tobacco history, stage, histology, locoregional versus systemic treatment, metastases observed throughout the course of treatment, and follow-up. For our case, we also describe chemotherapy and the radiation therapy course along with follow-up imaging to monitor treatment response.

\section{How to cite this article}

Sanwal C, Voorhees G, Moon A, et al. (February 26, 2019) A Rare Case of Human Papillomavirusassociated High-grade Neuroendocrine Carcinoma of the Hypopharynx. Cureus 11(2): e4138. DOI 10.7759 /cureus. 4138 


\section{Cureus}

\section{Case Presentation}

We present a 23-year-old female with a past medical history of polycystic ovarian syndrome (diagnosed at the age of 15) and diabetes mellitus. She complained of persistent hoarseness, cough, and a decreased range of motion of her right neck, shoulder, and odynophagia. She rated her pain as six out of 10 . Her pain was $100 \%$ relieved with tramadol. She lost 41 pounds in two months. A computed tomography (CT) scan of her neck showed a markedly enlarged, right level, $2 / 3$ lymph node measuring $3.5 \times 4.1 \times 4.6 \mathrm{~cm}$ (Figures 1 -2). There was also left level, 2/3 lymph nodes measuring up to $0.8 \times 1.5 \mathrm{~cm}$. The right aspect of the supraglottic larynx was asymmetrically thickened at $10 \mathrm{~mm}$ versus $3 \mathrm{~mm}$ on her contralateral left side.

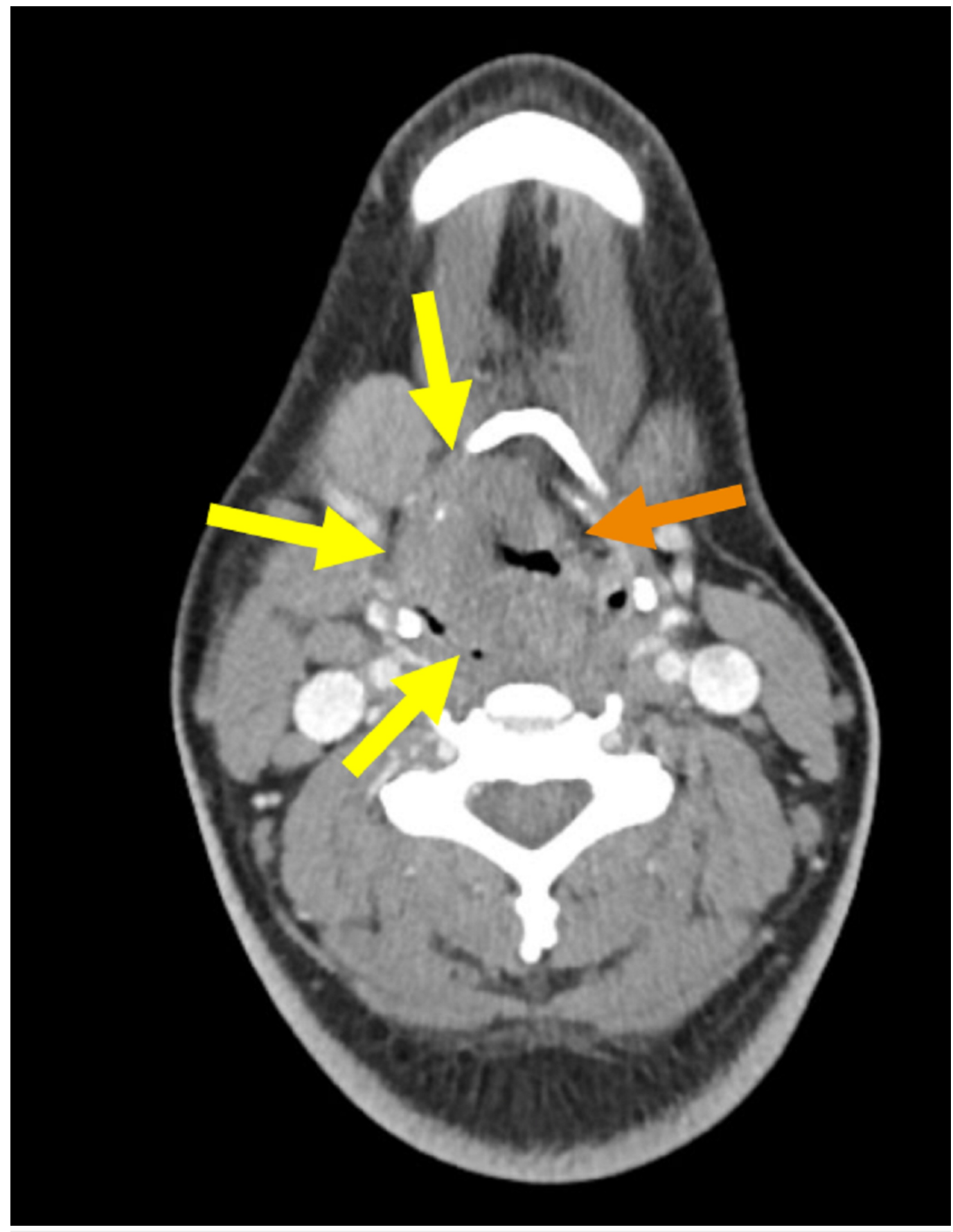

FIGURE 1: Axial contrast-enhanced computed tomography (CT) image of the neck. Yellow arrows indicate the mass (located within the right hypopharynx). Orange arrow signals the 


\section{Cureus}

\section{normal contralateral left hypopharyngeal wall.}

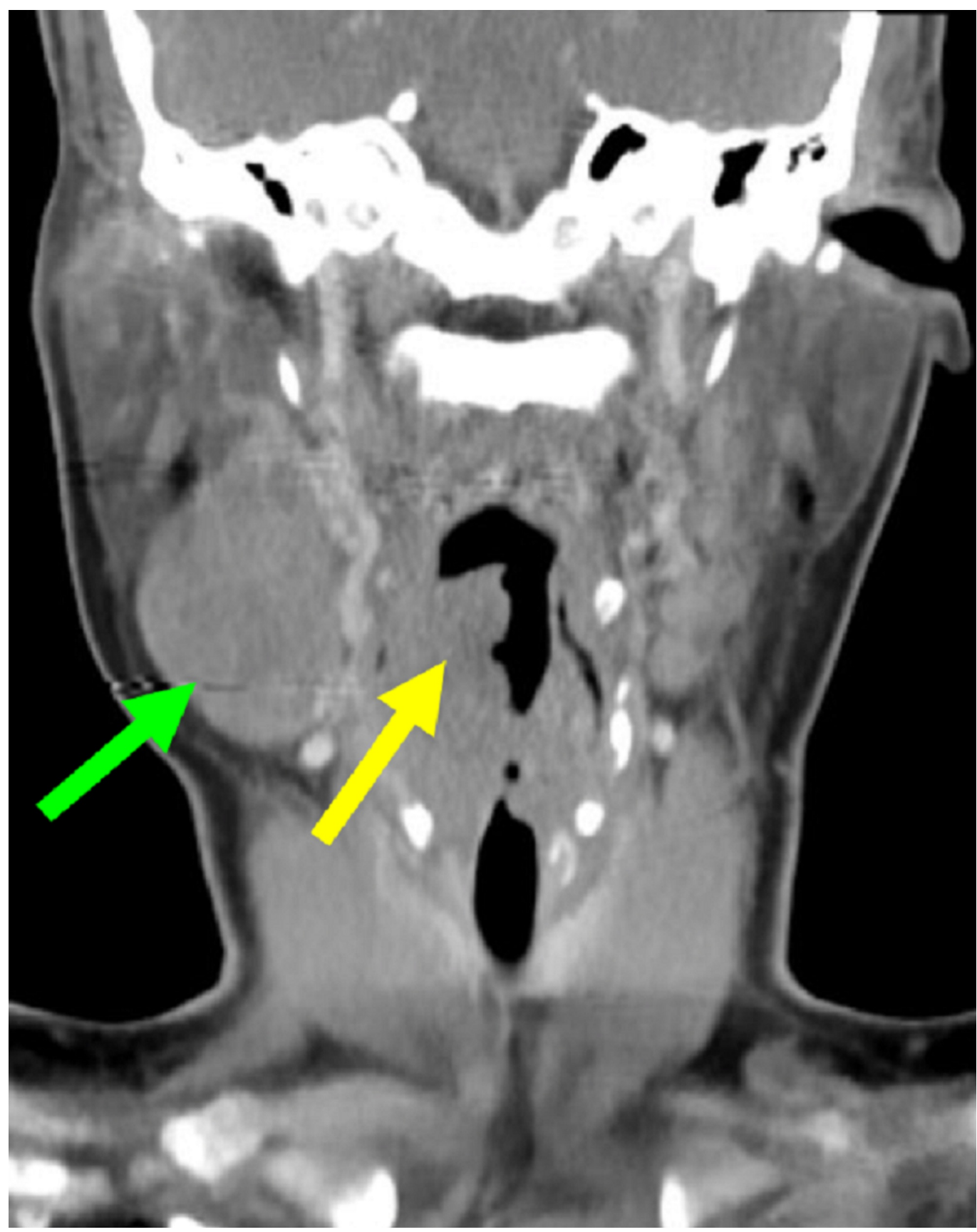

FIGURE 2: Coronal contrast-enhanced computed tomography (CT) image of the neck. Green arrow labels the right enlarged cervical lymph node. Yellow arrow indicates the primary hypopharyngeal mass.

The patient was evaluated by Ear, Nose, and Throat (ENT). Fiber-optic laryngoscopy showed her epiglottis was thickened and the right side was pushed to the left. She had a right pyriform mass with a fixed right true vocal cord and thickening of her right false vocal cord. Positron emission tomography (PET) scan showed a prominent, right-sided, hypopharyngeal, 


\section{Cureus}

hypermetabolic mucosal mass consistent with a primary tumor involving her right vallecula, epiglottis, piriform sinus, and supraglottis (Figures 3-4).

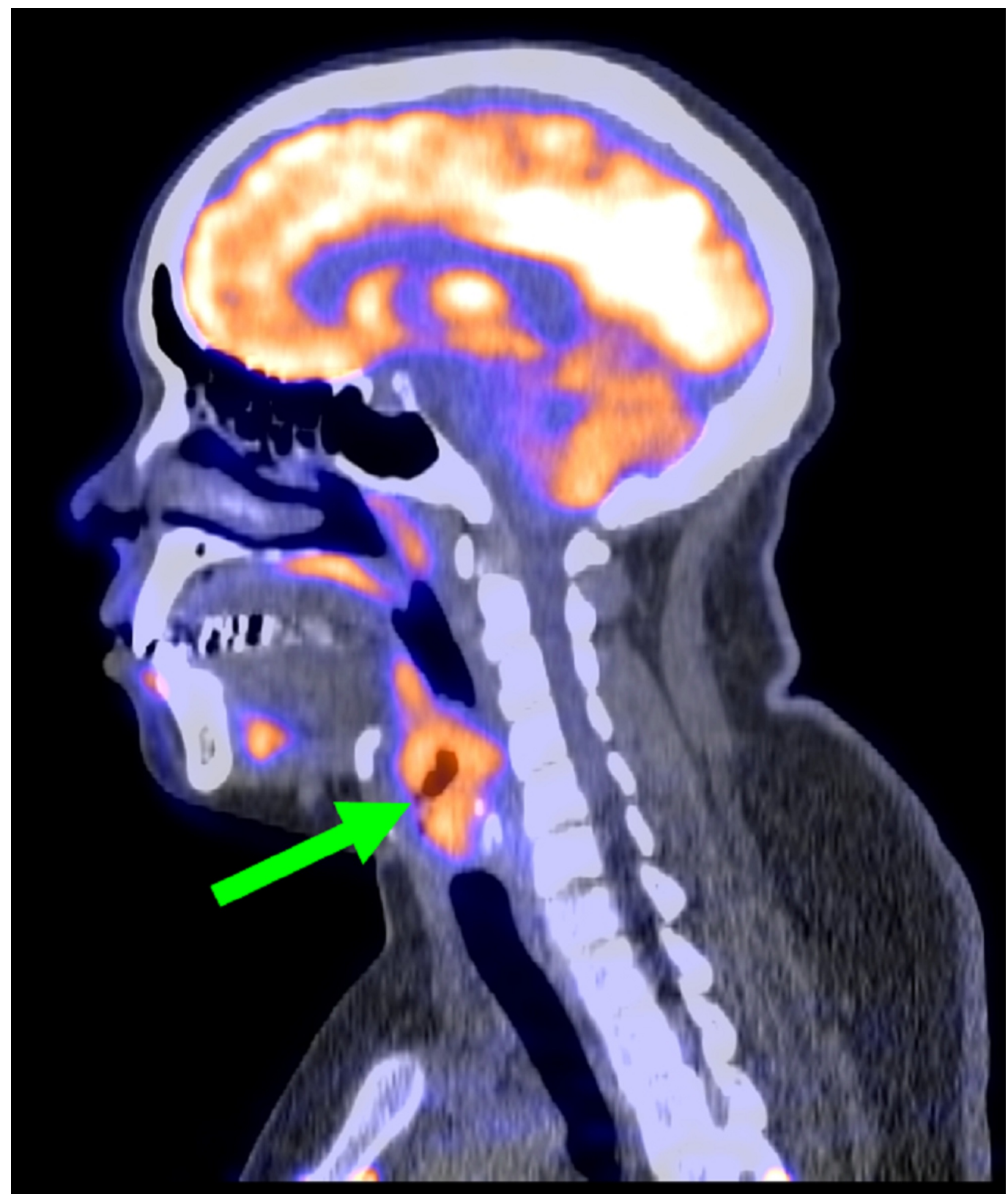

FIGURE 3: Sagittal positron emission tomography (PET) image of the neck. Green arrow labels a large, right level, 2-3 cervical node. 


\section{Cureus}

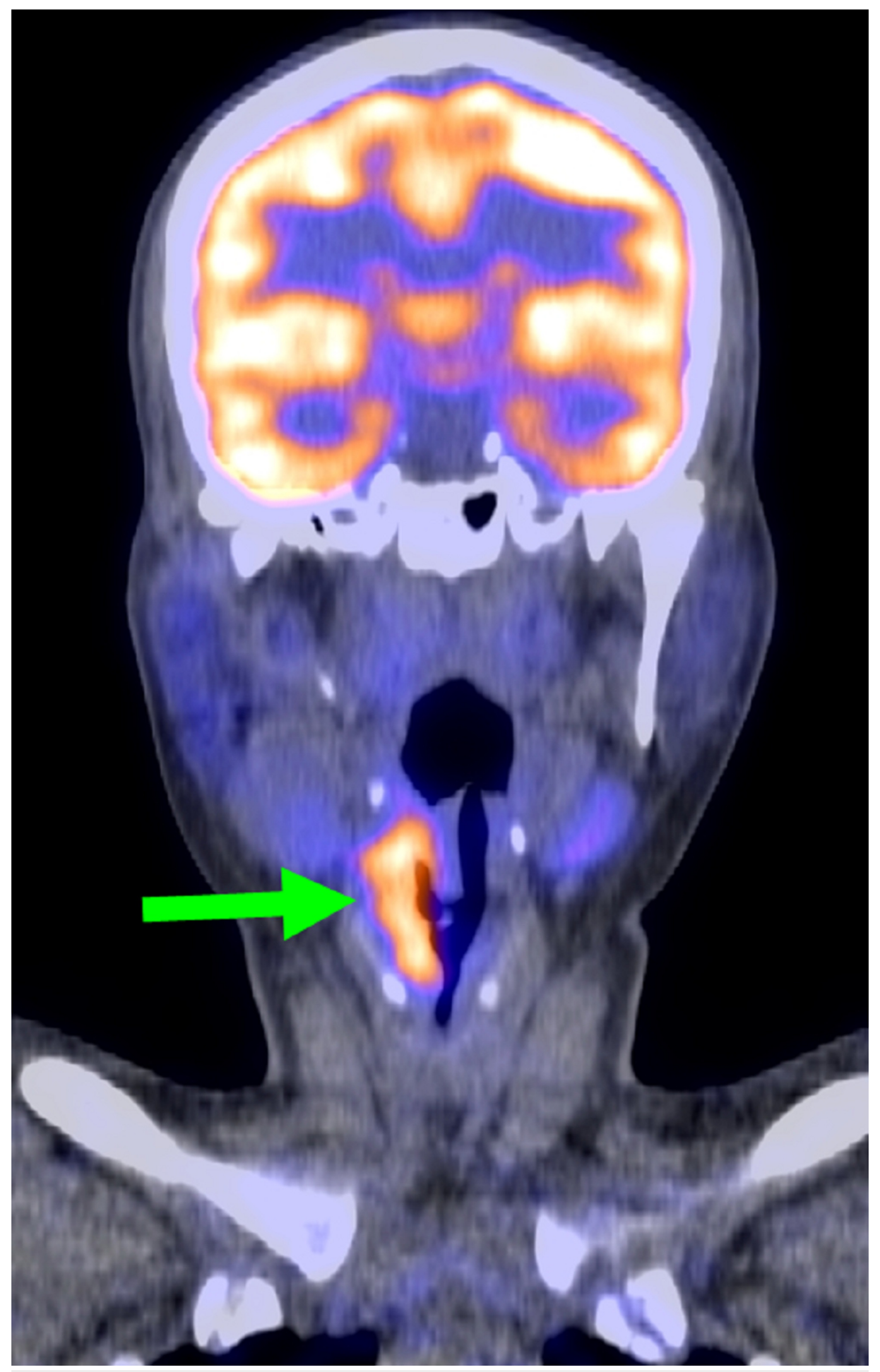

FIGURE 4: Coronal positron emission tomography (PET) image of the neck. Green arrow indicates the hypermetabolic, hypopharyngeal mass. This image is after the patient's initial two cycles of chemotherapy. The metastatic cervical lymph 
Ipsilateral hypermetabolic $4.9 \mathrm{~cm}$ level $2 \mathrm{~A}$ and 3 hypermetabolic lymph nodes were seen. Subcarinal and left hilar hypermetabolic lymphadenopathy suspicious for nodal chest involvement was noted. An ultrasound-guided biopsy and fine needle aspiration (FNA) of the anterior cervical lymph node showed a small round cell tumor, favoring high-grade neuroendocrine carcinoma (Figure 5). A bone marrow biopsy showed normocellular bone marrow. No morphological or histochemical support for metastatic tumor was noted.

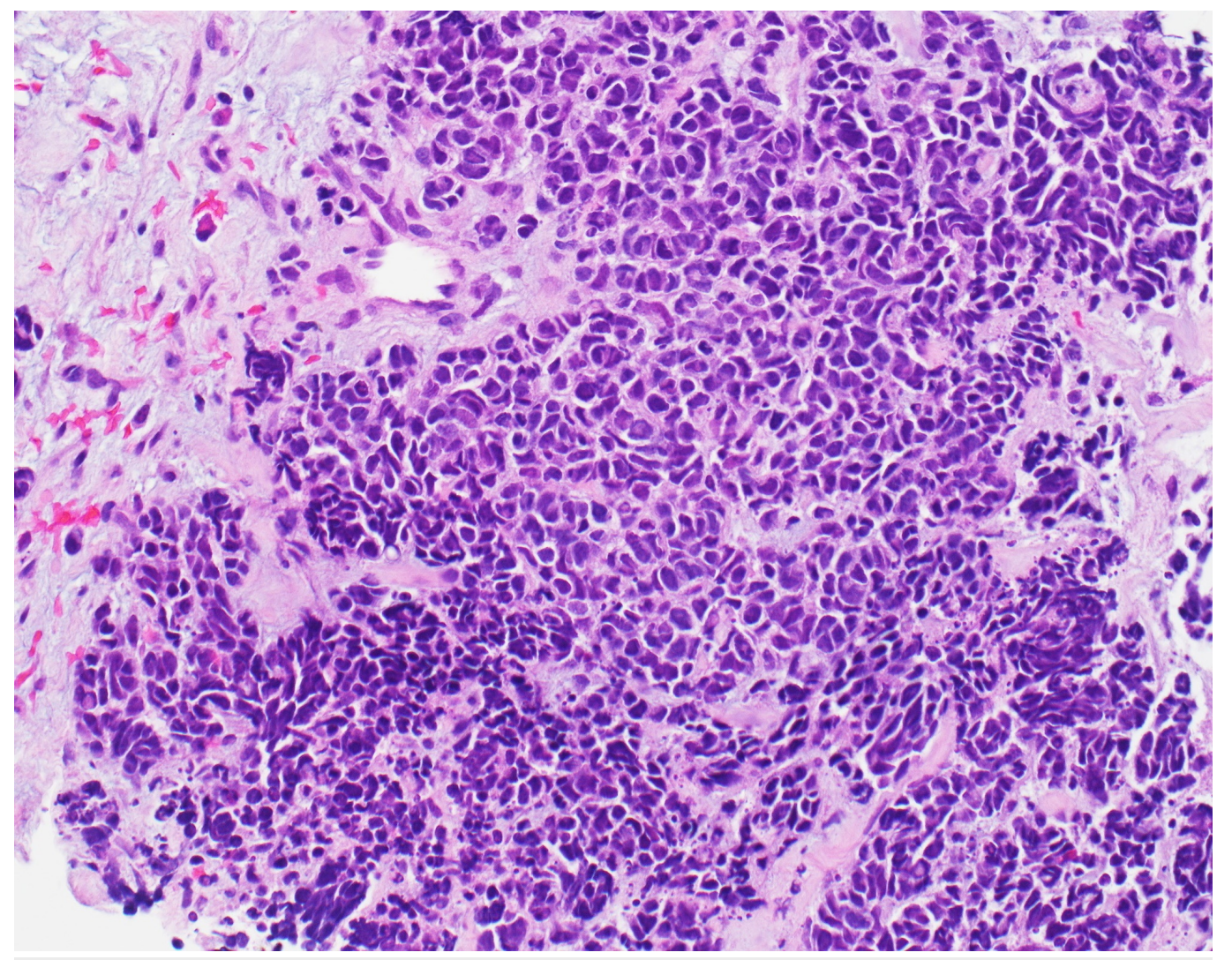

FIGURE 5: Histopathology of her neck mass shows small round blue cells. The cell borders are indistinct within the clusters of epithelium, with focal crush artifact and nuclear molding noted, characteristic of a poorly differentiated neuroendocrine neoplasm.

Pathology confirmed tumor expression of the p16 marker related to high-risk HPV (Figure 5). Eight HPV subtypes 16, 18, 31, 33, 35, 45, 52, and 58 were identified by ribonucleic acid (RNA) in-situ hybridization.

She received a total of six cycles of chemotherapy with cisplatin and etoposide. Two cycles were given neoadjuvantly, three were given concurrently with $70 \mathrm{~Gy}$ of localized radiation therapy, and the last cycle was given post-radiation therapy. After an initial two cycles of chemotherapy, a repeat PET scan showed a decrease in fluorodeoxyglucose (FDG) metabolism of the mass with no additional FDG-avid metastatic lesions. Resolution of the previously seen 


\section{Cureus}

subcarinal and left hilar lymphadenopathy with no FDG uptake was also noted. After treatment, she had subjective improvement with increased neck range of motion, reduced odynophagia, and hoarseness.

\section{Discussion}

Neuroendocrine (NECC) cancers have a combination of hormone-producing endocrine cells and nerve cells. Neuroendocrine cells are found throughout the body in organs such as the lungs and gastrointestinal tract, including the stomach and intestines. Neuroendocrine tumors can be found in all age groups, including children and young adults [3].

Small cell carcinoma (SCC) is one of many subtypes of NECC based on specific histologic and immunohistochemical properties [4-6]. SCC is most commonly found in the lung [1]. Extrapulmonary sites (EPS) are uncommon and account for only $2.5 \%-5 \%$ of all SCCs [1]. These most common EPS include the larynx, esophagus, and bladder [1]. The larynx is the most common EPS site in the head and neck and comprises $<0.5 \%$ of all primary laryngeal carcinomas [1]. The hypopharynx has close proximity to the larynx and SCC of hypopharynx (SCCH) are extremely rare [1,7]. There are only 11 confirmed cases of SCCH to date [2]. This is the twelfth case of SCCH. This case report presents a comparison of SCCH with the previously reported 11 cases in terms of its common features and rare characteristics (Table 1).

\begin{tabular}{|c|c|c|c|c|c|c|c|c|c|c|}
\hline (\#)Authors & Year/age/sex/smoking & $\begin{array}{l}\text { Stage } \\
\text { (TNM) }\end{array}$ & $\begin{array}{l}\text { Main } \\
\text { symptom }\end{array}$ & $\begin{array}{l}\text { Site/extent of } \\
\text { lesion at } \\
\text { presentation }\end{array}$ & Histology & $\begin{array}{l}\text { Locoregional } \\
\text { Tx }\end{array}$ & $\begin{array}{l}\text { Adjuvent } \\
\text { Tx }\end{array}$ & $\mathrm{PCl}$ & $\begin{array}{l}\text { Metastases } \\
\text { (observed } \\
\text { throughout } \\
\text { the course) }\end{array}$ & Follow-up \\
\hline $\begin{array}{l}\text { (1) Ferlito } \\
\text { and } \\
\text { Polidoro }\end{array}$ & 1980/57/M/+ & T1N2bM0 & Neck mass & PS/LR & $S Q C+S C C$ & $\begin{array}{l}\text { Radical Sx + } \\
\text { RT }\end{array}$ & None & - & $\begin{array}{l}\text { Cervical } \\
\text { nodes, bone, } \\
\text { soft tissue }\end{array}$ & $\begin{array}{l}\text { Died of cancer } \\
3.5 \text { months after } \\
\text { diagnosis }\end{array}$ \\
\hline $\begin{array}{l}\text { (2) Mills et } \\
\text { al. }\end{array}$ & 1983/49/M/+ & NA & $\begin{array}{l}\text { Neck mass, } \\
\text { dysphagia, } \\
\text { weight loss }\end{array}$ & PS/LR & $\mathrm{SQC}+\mathrm{SCC}$ & $\begin{array}{l}\text { Radical Sx + } \\
\text { RT }\end{array}$ & None & - & Cervical nodes & $\begin{array}{l}\text { Alive free of } \\
\text { cancer } 6 \text { months } \\
\text { after treatment }\end{array}$ \\
\hline $\begin{array}{l}\text { (3) Baugh } \\
\text { et al. }\end{array}$ & 1985/63/F/- & $\begin{array}{l}\text { T4a, more } \\
\text { than N2c, } \\
\text { M0 }\end{array}$ & $\begin{array}{l}\text { Dysphagia, } \\
\text { cervical mass }\end{array}$ & PS/LR & SCC & $\begin{array}{l}\text { Incomplete } \\
\text { Sx }\end{array}$ & $>4$ & - & Cervical nodes & $\begin{array}{l}\text { Alive free of } \\
\text { cancer } 55 \\
\text { months after } \\
\text { diagnosis }\end{array}$ \\
\hline $\begin{array}{l}\text { (4) Baugh } \\
\text { et al. }\end{array}$ & 1985/35/M/- & T3N2aM0 & $\begin{array}{l}\text { Dysphagia, } \\
\text { weight loss }\end{array}$ & $\begin{array}{l}\text { Base of tonsil to } \\
\text { PS/LR }\end{array}$ & SCC & RT & None & - & Cervical node & $\begin{array}{l}\text { Alive free of } \\
\text { cancer } 21 \\
\text { months after } \\
\text { diagnosis }\end{array}$ \\
\hline $\begin{array}{l}\text { (5) Gaba } \\
\text { et al. }\end{array}$ & 2005/65/M/ex+ & T4aN1M0 & $\begin{array}{l}\text { Dysphagia, } \\
\text { weight loss }\end{array}$ & PS/LR & SCC & $\begin{array}{l}\text { Incomplete } \\
\text { Sx + CRT }\end{array}$ & $>4$ & - & Cervical node & $\begin{array}{l}\text { Alive free of } \\
\text { cancer more } \\
\text { than } 24 \text { months } \\
\text { after diagnosis }\end{array}$ \\
\hline $\begin{array}{l}\text { (6) Sano et } \\
\text { al. }\end{array}$ & 2005/67/F/+ & NA & Neck mass & PS/LR & SCC & RT & $<4$ & - & $\begin{array}{l}\text { Cervical node, } \\
\text { lung, liver }\end{array}$ & $\begin{array}{l}\text { Died of cancer } \\
13 \text { months after } \\
\text { diagnosis }\end{array}$ \\
\hline & & & & & & & & & Cervical and & \\
\hline
\end{tabular}




\section{Cureus}

\begin{tabular}{|c|c|c|c|c|c|c|c|c|c|c|}
\hline $\begin{array}{l}\text { (7) Uwa et } \\
\text { al. }\end{array}$ & 2013/73/M/+ & T4aN2bM0 & Neck mass & PS/LR & $S Q C+S C C$ & Radical Sx & None & - & $\begin{array}{l}\text { mediastinum } \\
\text { nodes, liver, } \\
\text { lung }\end{array}$ & $\begin{array}{l}\text { Died of cancer } 9 \\
\text { months after } \\
\text { treatment }\end{array}$ \\
\hline $\begin{array}{l}\text { (8) Bayram } \\
\text { et al. }\end{array}$ & 2015/50/M/+ & $\begin{array}{l}\text { T4aN2bM1 } \\
\text { (lung) }\end{array}$ & $\begin{array}{l}\text { Severe } \\
\text { respiratory } \\
\text { distress }\end{array}$ & PS/LR & SCC & $\begin{array}{l}\text { Incomplete } \\
\text { RT }\end{array}$ & $<4$ & - & $\begin{array}{l}\text { Cervical and } \\
\text { lung }\end{array}$ & $\begin{array}{l}\text { Alive free of } \\
\text { cancer } 15 \\
\text { months after } \\
\text { treatment }\end{array}$ \\
\hline $\begin{array}{l}\text { (9) Misawa } \\
\text { et al. }\end{array}$ & 2016/74/M/+ & T2NOMO & $\begin{array}{l}\text { Throat pain, } \\
\text { hoarseness }\end{array}$ & PS/Local & $S Q C+S C C$ & CRT & None & - & Bone & $\begin{array}{l}\text { Died of cancer } 7 \\
\text { months after } \\
\text { treatment }\end{array}$ \\
\hline $\begin{array}{l}(10) \\
\text { Nakahira } \\
\text { et al. }\end{array}$ & $2017 / 75 / \mathrm{M} /+$ & $\begin{array}{l}\text { T2N2cM1 } \\
\text { (bone) }\end{array}$ & Dysphagia & PS/LR-distant & $S Q C+S C C$ & None & $>4$ & - & Bone, liver & $\begin{array}{l}\text { Died of cancer } 6 \\
\text { months after } \\
\text { treatment }\end{array}$ \\
\hline $\begin{array}{l}\text { (11) } \\
\text { Nakahira } \\
\text { et al. }\end{array}$ & 2017/73/M/- & T3N2bM0 & Dysphagia & PS/LR & $S Q C+S C C$ & $\begin{array}{l}\text { Radical Sx + } \\
\text { RT }\end{array}$ & $>4$ & + & $\begin{array}{l}\text { Cervical } \\
\text { nodes, lung }\end{array}$ & $\begin{array}{l}\text { Alive with cancer } \\
26 \text { months after } \\
\text { treatment }\end{array}$ \\
\hline (12) & & & & & & & & & & Alive free of \\
\hline $\begin{array}{l}\text { Sanwal et } \\
\text { al. }\end{array}$ & 2018/23/F/Ex-smoker+ & T3N3M0 & Dysphagia & PS/LR & & CRT & $>4$ & - & Cervical nodes & $\begin{array}{l}\text { cancer } 1 \text { month } \\
\text { after treatment }\end{array}$ \\
\hline
\end{tabular}

\section{TABLE 1: Comparison of clinicopathological features of 11 previous cases of SCCH and our case}

For more details please refer [2]. SCCH: Small Cell Carcinoma of Hypopharynx; PS: Piriform Sinus; LR: Locoregional; SCC: Small Cell Carcinoma; SQC: Squamous Cell Carcinoma; CRT: Chemoradiation Therapy; RT: Radiation Therapy; PCI: Prophylactic Cranial Irradiation; Sx: Surgery; Tx: Treatment

Our patient's age of 23 years is the lowest among all previously reported cases, with an age range of 35-75. HPV associations with various types of NECCs of the head and neck have been reported. For instance, there are case reports of HPV-associated large cell NECCs of the head and neck and HPV-associated SCC of the oropharynx [8-10]. The association of HPV with SCC of the hypopharynx is a rare new entity. Pathology confirmed the tumor expression of the p16 marker related to high-risk HPV. Eight HPV subtypes 16, 18, 31, 33, 35, 45, 52, and 58 were identified by RNA in-situ hybridization. Some of the important common features among all the 12 cases (previously reported 11 and our case) include: (a) piriform sinus of the hypopharynx as the primary site in all cases; (b) a majority of patients presented with dysphagia and neck mass; and (c) most patients had locoregional involvement at the time of presentation as opposed to distant metastasis.

The therapeutic approach to NECC is guided by its proper characterization, whether it is pure large cell, pure squamous cell, pure small cell, or mixed type with or without HPV association $[2,4]$. HPV-associated SCC of the oropharynx is reported to have improved clinical outcomes [9].

SCC has a poor prognosis with a reported median survival of two to four months without treatment [1]. Surgery (total laryngectomy) alone does not improve local tumor control and 
decreases the quality of life $[2,4]$. Radiation therapy didn't improve survival but it was successful in controlling the primary tumor site [4]. The combination of primary radiation therapy and adjuvant chemotherapy resulted in median survival of 55 months, representing a significantly longer overall survival than any other treatment regimens [4]. The recommended treatment is four to six cycles of etoposide plus platinum-based agents such as carboplatin and cisplatin [2]. As chemotherapeutic agents do not penetrate the blood-brain barrier, prophylactic cranial irradiation has been suggested as part of the management of this cancer [4]. Due to the very small number of reported cases of $\mathrm{SCCH}$, the treatment guidelines are similar to that of SCC of the lung and there are no targeted therapies unique to SCCH [2]. Furthermore, HPVassociated SCCH is extremely rare with potentially aggressive clinical behavior and needs much more research to further elucidate both the diagnostic and therapeutic approaches.

\section{Conclusions}

In all cases of SCCH reported to date, the primary site is found to be the piriform sinus of the hypopharynx. SCCH is a rare form of cancer, and unlike SCC of the lung, SCCH does not have any standard guidelines for its diagnosis and treatment. HPV-associated SCCH is even rarer. There is evidence that HPV-associated small cell of the oropharynx has improved clinical outcomes. It is yet to be researched how the association of HPV with SCCH impacts the disease prognosis and treatment. Hence, $\mathrm{HPV}$-associated $\mathrm{SCCH}$ is a rare new entity with potentially aggressive clinical behavior and needs much more research to further elucidate its both diagnostic and therapeutic approaches.

\section{Additional Information}

\section{Disclosures}

Human subjects: Consent was obtained by all participants in this study. Conflicts of interest: In compliance with the ICMJE uniform disclosure form, all authors declare the following: Payment/services info: All authors have declared that no financial support was received from any organization for the submitted work. Financial relationships: All authors have declared that they have no financial relationships at present or within the previous three years with any organizations that might have an interest in the submitted work. Other relationships: All authors have declared that there are no other relationships or activities that could appear to have influenced the submitted work.

\section{Acknowledgements}

Thanks to Dr. Antonio Guzman, MD, for proofreading the case report.

\section{References}

1. Lee JH, Jeong JS, Kim SR: Small cell carcinoma of the pyriform sinus successfully treated with concurrent chemo-radiotherapy: a case report. Medicine (Baltimore). 2016, 95:e4759. 10.1097/MD.0000000000004759

2. Nakahira M, Kuba K, Matsumura S, Sugasawa M: Primary small cell carcinoma of the hypopharynx: a report of two cases and review of nine additional cases. Case Rep Otolaryngology. 2017, 2017:8143145. 10.1155/2017/8143145

3. Navalkele P, O'Dorisio M, O'Dorisio T, Lynch C: Neuroendocrine tumors in children and young adults: incidence, survival, and prevalence in the United States. J Clin Oncol. 2010, 39:278. 10.1097/01.mpa.0000363933.98540.e2

4. Kumar LP, Armugham N, Triveni B, Krishna MR: Neuroendocrine tumor of larynx: a review of literature. Asian J Oncol. 2015, 1:33-36. 10.4103/2454-6798.165092

5. Zhu Y, Gao L, Meng Y: Laryngeal neuroendocrine carcinomas: a retrospective study of 14 cases. Biomed Res Int. 2015, 2015:832194. 10.1155/2015/832194

6. Lee WI, Ameratunga M, du Plessis J: Hypopharyngeal large cell neuroendocrine carcinoma. 


\section{Cureus}

BMJ Case Rep. 2015, 2015:bcr2015211908. 10.1136/bcr-2015-211908

7. Takagawa R, Tanaka K, Yamada M, Nojiri K, Kumamoto T, Ueda M, Endo I: Primary neuroendocrine carcinoma of the hypopharynx: a case report. Dis Esophagus. 2011, 24:26-31. 10.1111/j.1442-2050.2011.01191.x

8. Thompson ED, STelow EB, Mills SE, Westro WH, Bishop JA: Large cell neuroendocrine carcinoma of the head and neck: a clinicopathologic series of 10 cases with an emphasis on HPV status. Am J Surg Pathol. 2016, 40:471-478. 10.1097/PAS.0000000000000580

9. Kraft S, Faquin WC, Krane JF: HPV-associated neuroendocrine carcinoma of the oropharynx: a rare new entity with potentially aggressive clinical behavior. Am J Surg Pathol. 2012, 36:321330. 10.1097/PAS.0b013e31823f2f17

10. Misawa K, Kawasaki H, Matsuo R: Human papillomavirus-associated small cell carcinoma/neuroendocrine carcinoma of the oropharynx: a report of two cases. SpringerPlus. 2016, 5:1847. 10.1186/s40064-016-3501-X 